Law in the Digital Age. 2021. Vol. 2, no. 3.

Вопросы права в цифровую эпоху. 2021. Т. 2. № 3.

Research article

УДК 349.3

DOI: $10.17323 / 2713-2749.2021 .3 .151 .167$

\title{
COVID-19: Legal Regulation of Universal Vaccination
}

\section{目 Alexander S. Kornienko', Nikolai A. Samokhvalov ${ }^{2}$}

${ }^{1}$ National Research University the Higher School of Economics, Moscow, Russia. akornienko@hse.ru, ORCID: 0000-0002-0759-2921

${ }^{2}$ Balakovo branch of RANEPA, Balakovo, Russia. nikolai-samohvalov@yandex.ru, ORCID: 0000-0002-2388-0472

\section{国国 Abstract}

The topic of this article is relevant, first of all, due to the fact that at the moment it is objectively impossible to deny the acquisition of the COVID-19 pandemic and its consequences as a kind of main indicator of socio-economic processes and a mechanism for legitimizing the state system of regulation and management in covid and post-covid conditions. The subject of the article is the legal regulation of mandatory vaccination against COVID-19. The purpose of the study is to identify the problems of legal regulation of the process of mandatory vaccination against COVID-19 through the prism of the human right to health protection and medical care in the system of universal values. This research is based on a combination of groups of general scientific methods (induction, deduction, analysis, synthesis) and special methods of legal science (formal legal, comparative legal and others). The authors carried out a conceptual analysis of the human right to health protection and medical care in the context of domestic law, as well as administrative and legal aspects of mandatory vaccination against COVID-19 based on the analysis of the generalized experience of two macro-regions of Moscow and the Moscow region. According to the results of the study, the authors come to the following key conclusions: firstly, the chief state sanitary doctor of the subject of the Russian Federation has an objective right dictated by the norms of domestic legislation to issue an executive-executive-administrative act on the mandatory vaccination in a pandemic; secondly, the employer is obliged to suspend from work (not to hire) citizens who refused vaccination only if it is a question of works named in the List of works, the performance of which is associated with a high risk of infectious diseases. Such measures cannot be applied to employees performing other types of work; thirdly, failure by an organization/individual entrepreneur to comply with the 
resolution of the chief state sanitary doctor entails appropriate measures of legal responsibility provided for by the norms of the current legislation of the Russian Federation.

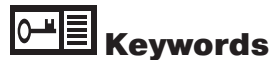

the human right to health protection and medical care, COVID-19, pandemic, restrictions, anti-medical measures, Chief sanitary doctor, mandatory vaccination, administrative and legal regulation.

For citation: Kornienko A.S., Samokhvalov N.A. COVID-19: Legal Regulation of Universal Vaccination. Legal Issues in the Digital Age. 2021, no. 3, pp. 151-167. DOI: $10.17323 / 2713-2749.2021 .3 .151 .167$

\section{Introduction}

The COVID-19 pandemic, which started in 2020, has informed the processes that have exercised a mostly destructive influence on the majority of systemically important clusters of the socio-economic space of the Russian Federation. Several months from now, it is going to be 2 years since the first case of the new infectious disease was first recorded in the RF. According to an expert estimate of Federal Service for Surveillance on Consumer Rights Protection and Human Wellbeing (Rospotrebnadzor) chief officer Anna Popova, "The first case of COVID-19 in Russia was recorded on March 1, 2020. The two cases of the illness brought from the People's Republic of China in February 2020 are not taken into account." ${ }^{1}$

So, soon it is going to be two years since the nation was first exposed to the new infection it is struggling to contain - this period is long enough to provide a sufficient number of observations for analyzing the dynamically changing situation and revisiting the current models of behavior and the relevant legislation. In particular, it is now obvious that because healthcare facilities are used to full capacity due to the COVID-19 pandemic, society and the state are faced with the challenges of modernizing the constitutional foundation of the right to health protection and medical assistance / medical care. These writers consider that in view of the special status this right is accorded in the RF's Constitution, the state and society should focus their efforts on bringing this right in line with modern realities.

\footnotetext{
${ }^{1}$ Available at: https://www.interfax.ru/russia/709883 (accessed: Aug.10, 2021)
} 
The COVID-19 response measures in Russia are quite varied, although vaccination has been prioritized, according to experts [Surovenko T.N., 2021: 70-77]; [Kharchenko E.P., 2021: 4-19]. In view of the above, the vaccination campaign's most contentious aspects are administrative and legal, related to legitimation of the vaccination in the Russia's legal space. In particular, it was for the first time that Moscow mayor and the governor of Moskovskaya Oblast' (Moscow Area) introduced mandatory vaccination for certain groups of people pursuant to orders issued by chief public health officers ${ }^{2}$. The mentioned bylaws became a sort of catalyst for the start of the universal COVID-19 vaccination campaign across the country.

Certain issues of vaccination, including the COVID-19 vaccination, have been explored by scholars from different disciplines. Thus, legal aspects of this problem have been addressed by social scientists from Samoa [Ramona B., 2020: 116-125]; the USA [Caitlain L., 2020], the UK [Kevin H., Erin W., 2020]. In particular, the researchers explore how governments reconsider their strategies and change their vaccination policies. These writers agree with the mentioned researchers in that today there are two main approaches: informing people and giving them the freedom of choice (Russia, Germany, Austria) and mandatory vaccination (Saudi Arabia, Indonesia, Israel).

Looking from the perspective of the COVID-19 pandemic, some legal scholars [Hans-Uwe S., Alexander K., Martin B., 2020: 1-5]; [Maltezou C., Androula P., Athanasios T., 2021: 1-12] insist on the need for revising the international legal standards, norms and principles adopted and recommended by the World Health Organization (WHO) since they do not provide an unequivocal answer regarding mandatory vaccination and violate human rights. These writers consider this stance to be totally justified and subscribes to it because the existing international legal standards, norms and principles adopted and recommended by the WHO need to be brought up to date fast in order to become, at a supranational legal level, a guarantee of the entire array of anti-COVID measures carried out at national levels.

It would seem logical to suppose that the present realities of the COVID-19 pandemic and its consequences are poised to become, for a long time to come, the main focus of integrated research combining disciplines from different fields of social sciences and the humanities because

2 See: Order No. 1 of chief public health officer of Moscow. June 15, 2021. "On Prophylactic Vaccination of Certain Vulnerable Population Groups.” Available at: https://www.garant.ru/products/ipo/prime/doc/400799739/ (accessed: Aug. 12, 2021); order No. 3 of the chief public health officer of Moskovskaya Oblast'. June 16, 2021. "On Prophylactic Vaccination of Certain Vulnerable Population Groups.” Available at: https://rg.ru/2021/06/16/ mosobl-post3-reg-dok.html (accessed: Aug. 12, 2021) 
the current pandemic's influence on the classical socio-economic order and, therefore, legal order - appears to be exceptionally vast, multi-dimensional, and diverse.

\section{The human right to health protection and medical assistance in the framework of human rights}

Health in modern world is the supreme, foremost public good, and its importance is so great that its disappearance may render meaningless many other public goods. Besides, people's health is an element of the national safety framework in any state, which accounts for the special protection it enjoys and for its special legal regulation via relevant legal mechanisms.

The right to health protection and medical care, together with other rights, such as, for instance, the right to decent living standards, education, housing, work, social security and protection, form a single harmonious system of people's social rights. The right to health protection and medical assistance has all the characteristics and distinguishing features of this category of rights: they are needed in order to satisfy individuals' basic vital needs, the absence of which makes decent living impossible. Besides, this category of rights (in particular, the right for health protection) are the foundation on which the state's social order rests.

The right to health protection and the right to health mean somewhat different things because the right to health is a civil right. The right to health protection is a fundamental right enjoyed by Russian citizens because a separate constitutional provision, in Article 41 of the Russian Federation Constitution, establishes the right to health protection and medical care for every person and it can be argued that this right has some bearing on the state's obligation to protect people's health (enshrined in Part II of the Constitution). In view of the above, these writers subscribe to E.B. Luparev's and E.V. Yepifanova characterization of the state's obligation to protect people's health as "a system including healthcare in a broad socioorganizational sense as the state's activity aimed at ensuring a high level of people's health, as well as the narrowly defined sectoral activity - a system of disease control and prevention measures carried out by healthcare organizations" [Luparev E.B., Epifanova E.B., 2021: 67].

Another implication of the fact that this right is enshrined in the Constitution is that all non-Russian nationals residing in Russia are afforded opportunities to realize the right to health protection on an equal footing with Russian citizens, strictly in agreement with the supranational documents signed by Russia [Lukhtenkova Ya.S., 2018: 187]. 
This right has an especially noticeable synallagmatic quality, which is a very important function of practically any right: the need to bring into agreement private and public interests.

Now, after a general overview of the right to health protection, the essence of the right and its place in the legal landscape need to be addressed in more detail.

When this right is accorded the constitutional status, it is recognized as a foremost public good and value in the system of public goods and values, which forms the backbone of any social order; but this status also has another implication - the state assumes obligations to ensure and enforce this right since any state's preeminent mission is to prioritize this right as an essential human and civil right.

It follows from the above that if the right to health protection is established as a basic constitutional civil right, the state then is obligated to create an environment and a socio-economic system that are fit for the purpose and, taken together, would enable people to maintain, recover and strengthen their health. The latter aspect is one of the foremost and most valuable social goods for any person, irrespective of his/her ethnicity, religion, social position, etc. [Mironova O.A., 2018: 107].

Sure enough, the state's performance in meeting its obligations mentioned above depends on a great number of factors, the most vital among which are arguably political, economic, and cultural factors.

Perhaps it would not make sense to debate the significance of the above mentioned factors since each of them can either raise a country's living standards on the basis of this right or, to the contrary, turn these state obligations in a mere legal formality with no material basis. One of good examples of the latter is a situation of political instability (civil war), which significantly weakens the right to, and guarantees of, health protection, not to mention the impossibility of fully guaranteeing the right to life typical for such situations.

And when levels of economic development and social security in a country are low, economic factor has a significant impact on the level of medical care, which is what is happening now with medical care in the regions. When the situation in a country is unstable and the level of economic development is low, the financing of the country's healthcare institutions becomes reduced to a bare-bones minimum, the way it happened, for instance, in the 1990s.

Such indicators as the population's knowledge levels and its awareness of the themes and issues related to the protection of its own health are like- 
wise some of the fairly important factors that prevent living standards from slipping. And the lack of knowledge causes non-compliance with disease control and prevention norms, the spread of various transmissible diseases, bad habits, etc. The factors at the other end of the spectrum include strong awareness levels among the country's population, a strong economy and a facilitative political environment - taken together, they empower the state to competently fulfill its obligations with respect to ensuring guarantees for realizing the right to health protection and medical care.

As mentioned above, enforcing the right to the highest level of health, which is enshrined, inter alia, in the international human rights documents, belongs to everyone and depends on a very wide range of socioeconomic and political factors that create the environment beneficial for people's health. According to the Russian legislation, these factors include neither more nor less than acceptable and safe labor conditions, quality medicines, and medical assistance accessible to all. ${ }^{3}$

The right for health protection and medical care, as well as components of this right, are enshrined in numerous federal legal acts of the.

If we look specifically at healthcare organizations affiliated with the International Medical Cluster, their functioning is regulated by Federal Law No. 160-FZ of June 29, 2015 "On the International Medical Cluster and Introducing Amendments to Certain Legal Acts of the Russian Federation"4.

Summarizing the above, it seems safe to conclude that the constitutional right to health protection is quite an elastic concept, and yet, the process of realization of this right is fairly well detailed, so a thorough knowledge of this legal aspect enables one to competently adopt and implement measures for realizing this right in Russia.

The Constitution is the cornerstone of the country's legislation, as well as the foundation of the nation's current healthcare system. Absolutely every sector and sphere of the national legislation starts off with sections, chapters and articles of the Constitution. This is spheres of economy, taxation, social security, and law enforcement, as well as several other legal spheres.

Issue-specific legal acts elaborate on the articles of the Constitution, providing a more in-depth treatment to every aspect of health protection

3 The Labor Code of the Russian Federation. Federal Law No. 197-FZ. Dec.30, 2001; as amended June 28, 2021. Compendium of Laws of the Russian Federation. Jan. 7, 2002. No. 1. Art. 3.

${ }^{4}$ Federal Law No. 52-FZ June 29, 2015 "On International Medical Cluster and Introducing Amendments to Certain Legal Acts of the RF" (as amended on July 26, 2019). Compendium of Laws of the RF. July 6, 2015. No. 27. Art. 3951. 
and the delivery of medical care. Thus, for instance, several federal laws regulate and define:

the initiation and evolvement of relations in the area of the state's oversight of disease control and prevention; organization of the state's disease control and prevention service; prescription of various sanctions for unlawful acts in this field;

conceptual / notional framework. In particular, much attention is paid to defining such important concepts as medical intervention, a medical service, medical care, health protection, "health" as such, etc. A list of health protection principles including such important ones as the absence of the option of turning down medical assistance, quality and accessibility of medical assistance.

If it has been established that a medical intervention is necessary and ought not to be delayed, the law establishes conditions under which the consent of the patient or his/her legal representative can be dispensed with. Such conditions include illnesses that can be dangerous for people other than the patient; severe mental disorders; the patient's criminal record ${ }^{6}$.

There are other federal laws, which, firstly, make the state responsible for containing the spread of HIV infections in Russia. The law makes the executive organs and organs of local self-government responsible for fulfilling this obligation ${ }^{7}$. Secondly, the federal laws provide legal regulation of national policies to contain and combat tuberculosis, first of all for the purposes of health protection, disease and control prevention, and for other purposes ${ }^{8}$.

The healthcare reforms in Russia produced an array of legal acts related to health insurance: this proves the need to legislatively regulate social measures of disease control and prevention.

Law does not establish an order in which problems related to reproductive health should be regulated. This problem is presently very important

${ }^{5}$ Federal Law No. 52-FZ. March 30, 1999. "On Healthcare and Epidemiological Control" as amended on July 2, 2021. Compendium of Laws of the RF. April 5, 1999. No. 14. Art. 1650.

${ }^{6}$ Federal Law No. 323-FZ Nov. 21, 2011 "On the Basics of Health Protection in the RF” as amended on July 2, 2021. Compendium of Laws of the RF. Nov.28, 2011. No. 48. Art. 6724.

7 Federal law No. 38-FZ March 30, 1995 "On Prevention of HIV in the RF" as amended on July 2, 2021. Compendium of Laws of the RF, April 3, 1995. No. 14. Art. 1212.

8 Federal Law No. 77-FZ July 18, 2001 "On Prevention of Tuberculosis in the RF" as amended on May 26, 2021. Compendium of Laws of the RF. June 25, 2001. No. 26. Art. 2581. 
for our society because it is closely related to several others: demographic problems, family problems, problems of sterilization and castration, polls about sperm donation [Sivochalova O.V., Lineva O.I. et al., 2017: 39].

\section{Some comments on the place of biomedical law in Russia's legal space}

Presently biomedical law is just a theory, although federal lawmakers have been seriously contemplating the introduction of this new branch of law.

These writers expect that this branch would rest on a foundation of integrated studies combining legal and other disciplines. Presently there exists a vital need in such branch of law as healthcare law, but in order to qualify as a branch, healthcare law needs some fine tuning, in relation to legal science, the vast pool of medical knowledge, and ethics.

The state should realize that a biotechnological world order is irreversible and the body of law should be developed fast lest we find ourselves on the sidelines of the quickly evolving processes [Sokolova N.V., 2018: 89]. So these writers consider it necessary to introduce amendments to the federal legislation that would be in line with the rapid progress in biotechnology [Savoshchikova E.V., Gurnaya L.E., 2018: 219].

The subjective right to health in the framework of constitutional human rights and freedoms is distinctive because a state of health as such is one of the factors that have the greatest impact on every person's everyday living. Such problems as a poor health or various physical disabilities usually produce a negative effect on an affected person's way of living - they can limit such person in his/her choice of a profession or a school, sports or cultural activities, a religion, a place of residence; they can limit the affected person's options in terms of the exercise of main personal rights (e.g., freedom of movement) [Lastovetsky A.G., Kitanina K.Yu., Khromushin V.A., 2019: 76].

Establishing the right to health protection, the state, according to Article 41(2) of the Constitution, assumes the obligation to ensure protection of its citizenry's health, irrespective of the factors mentioned above, as well as protection of citizens residing or sojourning abroad on account of the international legal acts (for instane, the diplomats).

This article also defines the federal healthcare system, thus contributing to the constitutionalization of the right at issue.

According to Article 41 of the "Basics of Health Protection", the foundation of the state healthcare system is comprised of the following: 
federal executive organs responsible for health protection and their territorial organs;

executive organs of the constituent entities / regions responsible for health protection, healthcare administrations of other federal executive organs (except federal executive organs referenced in para 1);

organizations under the aegis of federal executive bodies, state academies of sciences, and executive organs of the constituent entities: medical and pharmaceutical bodies; healthcare bodies responsible for supervision of consumers rights protection and human welfare; forensic science institutions; other bodies and their non-local subsidiaries engaged in health protection $^{9}$.

The non-public healthcare system is usually comprised of medical care institutions which are organized by individuals or corporate entities and which contribute to ensuring people's right to health protection.

In the national and municipal healthcare systems citizens are already provided with medical assistance free of charge. The article of the Constitution quoted above references citizens as sole recipients of free-of-charge medical assistance. As for foreign nationals and stateless persons, Russia assumes an obligation to provide them with medical assistance in keeping with the Russian national healthcare standards set forth in order No. 186 of the Russian Federal Government, March 6, 2013 [Medvedeva O.V., Afonina N.A., Draenkova F.R., 2017: 21].

\section{Institutional underpinnings of the right to health protection at supranational level}

According to a human rights theory well known in international scholarship, even a formally established right creates an obligation for the state.

In the area under review, legal norms related to the state's positive obligations require active reciprocated interactions because in a globalized environment many legal issues, as well as some of the challenges related to human rights, can be handled only cooperatively.

From the standpoint of supranational law, the authority analyzed here also implies facilitating the improvement of population's health and living standards.

9 Federal Law No. 73-FZ May 31, 2001 "On State Forensic Expertise in the RF" as amended on July 1, 2021. Compendium of Laws of the RF. June 4, 2001. No. 23. Art. 2291. 
The institutionally anchored component, comprised of organizations participating in international healthcare cooperation, has three levels.

The first level is global. It includes global healthcare organizations.

The second level includes governmental and non-governmental organizations. They cooperate with each other over legal issues of healthcare, performing certain tasks in separate regions.

The third level is national healthcare agencies.

This level also includes such organizations as the International Red Cross and Red Crescent Movement.

The above organizations may be characterized as subjects of international cooperation.

Having addressed the third level of organizations, one can now proceed to review the constitutional right to health protection in the Commonwealth of Independent States and Russia in particular.

So, in the Russian legal system, healthcare is pivoted on a well-established hierarchy issuing from Article 41 of the Constitution.

The right to health protection, therefore, is hierarchichlly structured: the Constitution is the supreme law and it also anchores this right in subordinate legal acts [Tuchkova E.G., 2017: 60].

Given all of the above, it would seem safe to conclude that the right to health protection is quite securely established at the constitutional level in the RF, thanks to which the Russian legislation can be easily adapted to different healthcare challenges, and it is likewise solidly established at an international level, where efficient international organizations are comprised of member states that have more or less similar constitutional provisions with respect to the right at issue and, as a result, a consensus can be reached fairly easily.

\section{The mandatory nature of the vaccination requirements issued by the chief public health officer and the scope of their application}

During the COVID-19 pandemic special importance is attached to bylaws issued by chief public health officers of the RF and its regions because of these officers' legal status and core competence. So, an important question today is whether the requirements set forth in the public health officers' orders are imperative or non-binding for the addressees. The following pivotal points need to be emphasized: 
Firstly, presently the anti-COVID vaccinations are smoothly integrated into the vaccination schedule. Moreover, there were plans to include them into the national vaccination schedule. In particular, this proposal was set forth in draft law No. $1179765-7^{10}$, initiated by the federal government; the draft was passed by the Duma at the first reading but on June 15, 2021 it was voted down by the lower house and removed from the legislative agenda. These writers believe that the majority of the Duma's deputies were absolutely right rejecting this draft law because presently in Russia the COVID-19 vaccination remains voluntary, as required by the Russian law, despite certain exceptions to the rule.

Secondly, federal law No. 157-FZ Sept. 17, 1998 “On Immunoprophylaxis of Transmissible Diseases" contains a provision authorizing mandatory epidemiological situation in the RF becomes sufficiently bad, this law allows to prophylactically vaccinate Russian citizens.

And thirdly, federal law No. 52-FZ March 30, 1999, in Article 51(6), allows to regional chief public health officers and their deputies to issue bylaws (orders) on prophylactic vaccination of the entire population or specific population groups in regions within their purview. The only condition that must be met before the introduction of a mandatory vaccination regime is the presence of an objective risk of Russian citizens contracting transmissible diseases.

So, regional chief public health inspectors obviously have the right, enshrined in federal legislation, to issue orders about mandatory vaccination during a pandemic.

According to order No.1 issued by Moscow's chief public health officer on June 15, 2021, and order No.3 issued by the chief public health officer of Moskovskaya Oblast' on June 16, 2021, there are two main categories of persons who must be vaccinated: the first category includes staff members employed under employment contracts or independent contractor agreements by sole traders and corporate employers in fields listed in the orders (hereinafter referred to as staff members, independent contractors or, when the distinction does not matter, as jobholders). These writers use here the term "independent contractors" in line with the orders' terminology — the term refers to persons employed under independent contractor agreements by sole traders or corporate entities.

It should be pointed out that the vaccination requirement applies first of all to jobholders in businesses-to-consumer (B2C) services sectors. Interest-

${ }^{10}$ Draft law No. 1179765-7 "On Introducing Amendments to Art.9 of the Federal Law 'On Immunization Against Transmissible Diseases.”' Available at: URL: http://www.consultant.ru/cons/cgi/online.cgi? req=doc\&base $=$ PRJ\&n=207896 (accessed: Aug. 17, 2021) 
ingly, "commerce", listed in the order, does not contain a reference to retail in other words, from a formal point of view, the order equally applies to sellers dealing with corporate entities. But such interpretation, in these writers' opinion, does not conform with the orders' goal, which is to ensure epidemiological safety for people who directly come into contact with jobholders at $\mathrm{B} 2 \mathrm{C}$ services organizations. These writers, therefore, consider that the reference to commerce in the order should be interpreted as retail commerce. That said, one hopes to see in the nearest future an official clarification that would eliminate the risks of multiple interpretations of the text of the orders.

The second category includes public servants at national and municipal agencies in Moscow, as well as employees of Moscow's administration and its subordinate entities.

\section{Obligations and responsibility of employers in the context of the vaccination campaign}

Pursuant to the orders issued by chief public health officers of Moscow and Moskovskaya Oblast', corporate entities and sole traders working in the fields listed in the orders must do the following:

to organize a two-stage vaccination campaign. The first stage, prior to July 15, 2021: administering the first dose; the second stage, prior to August 15,2021 : administering the second dose, to as least $60 \%$ of jobholders.

A literal interpretation of the order suggests that the baseline for determining $60 \%$ is the total headcount of jobholders. The total count includes:

staff members and independent contractors;

adults as well as minors (of less than 18 years of age);

both unvaccinated persons (including persons with contraindications to vaccination) and persons already vaccinated;

jobholders whose duties are related to the lines of work listed in the orders and jobholders whose duties are not related thereto. These writers doubt the expediency of the latter requirement. However, lacking specialized knowledge in the area of epidemiology, they would recommend to rely on the literal interpretation of the orders' text.

So it is $60 \%$ of the overall number of jobholders that have to be vaccinated. In these writers' opinion, the orders' texts imply that individuals who became vaccinated independently of their employers can be included into the quota. The most essential thing is to ensure that $60 \%$ of all job- 
holders are vaccinated. The odds are, however, that the authorities may still insist that the reference headcount for $60 \%$ is still unvaccinated jobholders. For all that, it should be kept in mind that in any case an individual must give a voluntary, unforced consent to the medical intervention before being vaccinated.

It is thus up to jobholders themselves to decide whether to consent to the vaccination and they have the right to turn this option down. Corporate entities and individual entrepreneurs have no right to introduce any sanctions against jobholders who refuse to become vaccinated. Employers' options are limited to the following:

energizing efforts to educate their staff members, independent contractors about the need to observe the existing disease control and prevention norms designed to prevent COVID-19, emphasizing the need for vaccination as the key factor in the struggle against the disease.

The orders do not reference specific measures in relation to the administration of the prophylactic vaccines, so this is left to employers' discretion. One would assume that employers are expected to subcontract vaccination to healthcare providers and to afford their staff members, independent contractors the opportunity for the vaccination (grant them a release from work). Other measures can be applied as well: incentives such as bonuses, an additional day off work, etc.

The RF has the general rule that prophylactic vaccinations included in the official immunization schedule are provided free of charge for individuals who are being vaccinated. So, when staff members, independent contractors have mandatory health insurance policies and their employers organize a vaccination at a federal / municipal healthcare institution, they are not charged for the vaccination.

As for the COVID-19 awareness raising, it can include both verbal and written methods (hand-to-hand distribution / mailing of information leaflets, printouts, etc.) and can be carried out either by the employer or experts (doctors, medical researchers, etc.).

Moscow's mayor and the governor of Moskovskaya Oblast' imposed additional obligations on employers: in the period July 1-15, 2021 they had to submit reports about their implementation of the chief public health officers's requirements; these reports had to be submitted electronically, via employers' electronic accounts - in Moscow, on the site of the mayor and government of Moscow, and in Moskovskaya Oblast', on the regional portal of public services. 
If an employer fails to comply with the mandatory vaccination requirements set forth in the chief public health officers' orders, this employer, in these writers' opinion, may be in breach of Article 6. 3(2) of the Code of Administrative Offences (CAO). And if an action (inaction) causes someone's death or harm to someone's health, the offender is liable under Art. 6.3 (3) of CAO providing for more serious penalties.

At the core of every administrative offence, however, is the offender's culpability. It needs to be pointed out that a corporate entity / sole trader can be held charge with an administrative offence only when it has been established that this entity / sole trader was able to observe the norms and rules whose breach qualifies as an administrative offence but for some reasons deliberately neglected to use all methods and instruments at its disposal to ensure a full compliance. So, if an employer takes all necessary steps to ensure the vaccination and raise its jobholders' awareness of the issue but jobholders turn down the vaccination offer, this employer cannot be charged with an administrative offence on account of the failure to reach the $60 \%$ vaccination threshold as required in the orders.

It would appear advisable to document measures implemented to organize the vaccination and raise jobholder's awareness, and to obtain written refusals from jobholders who refuse to be vaccinated.

An employer's failure to fulfill the requirement, set forth in the orders, to submit the report electronically can be classified as an offence under Art. 20.6.1(1) of the CAO.

As for administrative sanctions against individuals who refuse to become vaccinated, these writers consider that it is impossible to apply any since individuals' right to turn down an offer of a vaccine is unconditional.

\section{Consequences of a jobholder's refusal to become vaccinated}

The Labor Code obligates employers to suspend jobholders from job duties or to withhold from them access to the workplace in some cases, as provided for, inter alia, in other federal laws and bylaws. It should be also noted that under Art. 76 (3) of the Labor Code, in the period when a jobholder is thus suspended from his/her duties, the employer has the right to withhold his/her pay for that period.

In particular, the following fact can be highlighted: federal law No. 157FZ Sept.17, 1998 “On Immunization Agains Transmissible Diseases” indeed 
contains a provision which, one the one hand, allows potential employers to turn down unvaccinated job seekers, and on the other, allows employers to suspend unvaccinated staff members from their job duties ${ }^{11}$. It should be remembered, however, that this norm applies only to those staff members whose professional duties expose them to a high risk of transmissible diseases. The list of such lines of work was compiled and officially approved by the federal government ${ }^{12}$. So, the employer arguably must suspend from duties (refuse to hire) individuals who refuse to become vaccinated only if the job at issue is included in the list of jobs exposing jobholders to a high risk of contracting transmissible diseases. Such measures may not be applied to staff members in other lines of work.

As for independent contractors, when such jobholder refuses to become vaccinated, a theoretically viable option would be raising the question of terminating the agreement on account of material changes in circumstances. These writerw wish to point out, however, that given the absence of a provision prohibiting hiring unvaccinated individuals under independent contractor agreements it seems unreasonable to argue that the circumstances have changed so greatly that had the parties been able to foresee such changes they would not have entered into the agreement or would have entered into an essentially different agreement; an independent contractor's refusal to become vaccinated, therefore, is not to be regarded as a material change of circumstances. Other implications in case of a refusal to become vaccinated, meanwhile, may be provided for in independent contractor agreements.

\section{Conclusion}

The experience of struggle against COVID-19 in different countries shows that in emergencies constitutional rights of individuals can be restricted and applied selectively, which calls into question the principle of equality of all before the law and equality of individuals' rights. The efficiency of legal regulation in this field and the controversial aspects of the application of law leave little doubt that the relevant regulatory frameworks have problematic aspects.

${ }^{11}$ Federal law No. 157-FZ Sept.16, 1998 “On Immunization Against Transmissible Diseases” as amended on July 2, 2021. Compendium of Laws of the RF. Sept. 21, 1998. No. 38. Art. 4736.

12 Order No. 825 of the Government of the RF (July 15, 1999) "On Approving the List of Jobs Which Expose Jobholders to High Risk of Contracting Transmissible Diseases and Require Prophylactic Vaccination" as amended on Dec.24, 2014. Compendium of Laws of the RF. July 19, 1999. No. 29. Art. 3766. 
According to the spirit of the modern civilizational theory, the right of an individual to health protection and medical care does not line up with the trajectory of individualism - rather, it becomes a composite value of any state and civil society. This right is singular because individuals do not obtain it over the course of their lives but have it since the moment of their birth, so this right cannot be taken away from them. Besides, this right implies that individuals should take adequate care of their health and, also, that the state should prioritize health needs of its citizens.

Two most important federal regions - Moscow and Moskovskaya Oblast' - became key drivers in the Russian national campaign of mandatory COVID-19 vaccination ${ }^{13}$. They largely charted the course of administrative and legislative regulation of this process, and their positive experience was adopted by other regions.

\section{D国 References}

1. Caitlain L. (2020) Legal Issues Related to the COVID-19 Outbreak: An Overview. Available at: https://crsreports.congress.gov (accessed: 29.08.2021)

2. Hans-Uwe S., Alexander K., Martin B. (2020) Strategies to Prevent SARS-CoV-2-Mediated Eosinophilic Disease in Association with COVID-19 Vaccination and Infection. International Archives of Allergy and Immunology, no 8, pp. 1-5.

3. Kevin H., Erin W. (2020) Legal Issues in COVID-19 vaccine development. Available at: https://crsreports.congress.gov (accessed: 29.08.2021)

4. Kharchenko E.P. (2021) Vaccines against COVID-19: Comparisons, Limitations, Waning of the Pandemic and Prospects of Viral Respiratory Infections. Epidemiologiya $i$ vaktsinoprofilaktika =Epistemiologia and Vaccinoprophilaktika, vol. 20, no. 1, pp. 4-19. (In Russ.).

5. Lastovetsky A.G., Kitanina K.Yu., Khromushin V.A. (2019) Evaluating the Performance of Healthcare Institutions and Healthcare Management Agencies. Vestnik nevrologii, psikhiatrii i neyrokhirurgii=Herald of Neurogy, Psyhiatry and Neurohirurgy, no 2, pp. 76-80. (In Russ.).

${ }^{13}$ The best practices of Moscow and Moskovskaya Oblast' in the field of implementation of the mandatory vaccination program has now been adopted by all regions. The regions have followed the suit of Moscow and Moskovskaya Oblast': first, the regions' chief public health inspectors issued the relevant orders; second, the authorities designated groups to be vaccinated; third, the authorities established timelines for administering the first and the second doses of the vaccine or the single-dose vaccine. Available at: URL: http://ivo.garant.ru/\#/document/77311703/paragraph/1:0 (accessed: Oct. 27, 2021) 
6. Luparev E.B., Epifanov E.V. (2021) Public Healthcare Law. Krasnodar: University, 191 p. (In Russ.).

7. Lukhtenkova Ya.S. (2018) Constitutional Right of Individuals for Medical Care and its Realization. Molodoy uchenyy=Young Researcher, no. 2, pp. 186-188. (In Russ.).

8. Maltezou C., Androula P., Athanasios T. (2021) Post-COVID Syndrome: An Insight on its Pathogenesis. Vaccines, no 9, pp. 1-12.

9. Medvedeva O.V., Afonina N.A., Draenkova F.R. (2017) The Legal Regulatory Framework for Social Protection of Disabled Person of Employable Age. Problemy sotsial'noy gigieny, zdravookhraneniya i istorii meditsiny = Social Hygiene, Healthcare and History of Medicine, no. 1, pp. 20-22. (In Russ.).

10. Mironova O.A. (2018) The Right to Health Protection: A Constitutional Dimension. Uchenye zapiski Krymskogo federal'nogo universiteta = Transactions of Crimean Federal University, vol. 4, no. 4, pp. 105-111. (In Russ.).

11. Ramona B. (2020) Capturing the Experiences of Samoa: The Changing Food Environment and Food Security in Samoa during the COVID-19 Pandemic. Oceania: a journal devoted to the study of the native peoples of Australia, New Guinea, and the Islands of the Pacific, no. 90, pp.116-125.

12. Savoshchikova E.V., Gurnaya L.E. (2018) Health Protection and Medical Care as a Constitutional Right of Individuals. Prodvinutaya nauka = Advanced Science, no. 2, pp. 217-221. (In Russ.).

13. Sivochalova O.V., Lineva O.I. et al. (2017) Protection of Reproductive Health and Family Planning. Moscow: INFRA-M, 326 p. (In Russ.).

14. Sokolova N.V. (2018) Issues of Ensuring Constitutional Right to Life and Health Protection in Russia and how to Address them. Uchenye zapiski Krymskogo federal'nogo universiteta = Transactions of Crimean Federal University, vol. 4, no. 2, pp. 88-94. (In Russ.).

15. Surovenko T.N., Glushkova E.F. (2021) Vaccinating against Flu During the COVID-19 Pandemic. Poliklinika = Clinic, no. 1, pp. 70-77. (In Russ.).

16. Tuchkova E.G. (2017) Basics of the Right to Social Security. Moscow: Prospekt, 416 p. (In Russ.).

\section{Information about the authors:}

A.S. Kornienko - Candidate of Sciences (Economics), Associate Professor;

N.A. Samokhvalov - Senior Lecturer.

The article was submitted 20.09.2021; approved after reviewing 11.10.2021; accepted for publication 01.11.2021. 